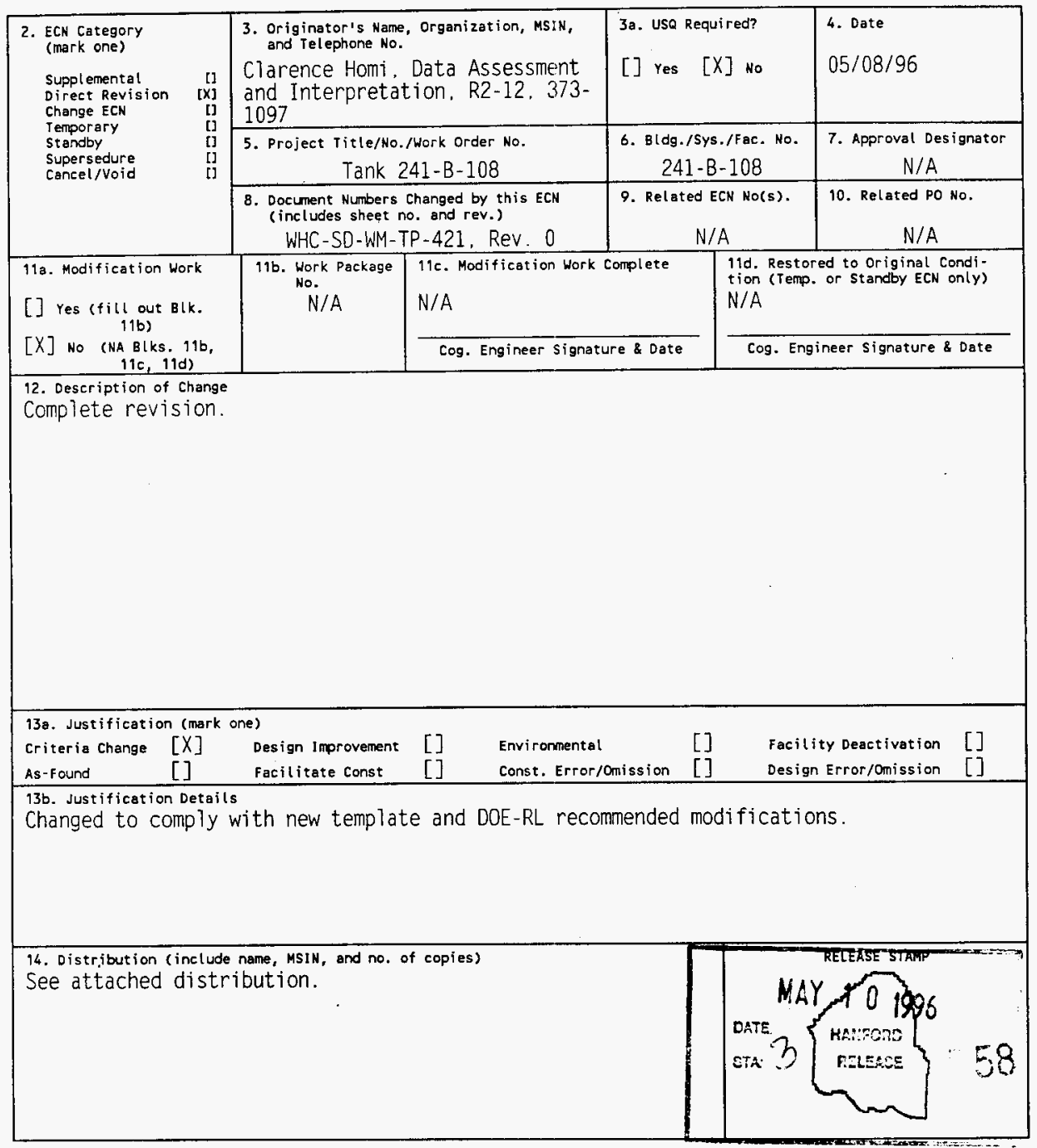




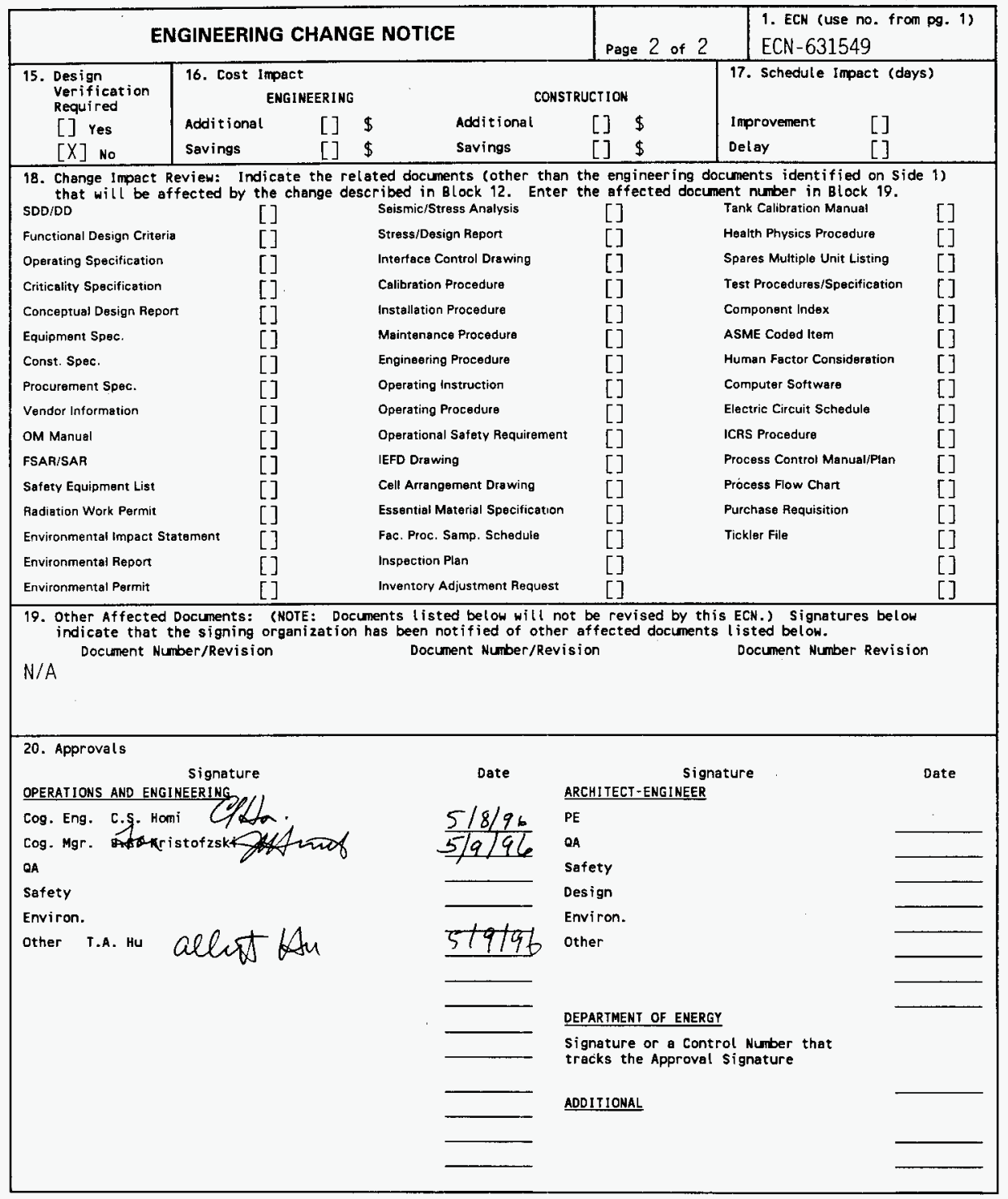


WHC-SD-WM-TP-421, Rev. 1

\title{
Tank 241-B-108 Tank Characterization Plan
}

\author{
C. S. Homi
}

Westinghouse Hanford Company, Richland, WA 99352

U.S. Department of Energy Contract DE-AC06-87RL10930

EDT/ECN : $\quad$ ECN-631549

Org Code: 79200

UC: 2070

B\&R Code: EW 3120074 Total Pages: $q$

Key Words: Characterization. General Safety Issues. Specific Safety Issues. Information Requirements, Schedule

Abstract: This document is a plan that identifies the information needed to address relevant issues concerning short-term and long-term storage and long-term management of single-she 11 tank 241-B-108.

TRADEMARK DISCLAIMER. Reference herein to any specific comercial product, process, or service by trade name, trademark, manufacturer, or otherwise, does not necessarily constitute or imply its endorsement, recommendation, or favoring by the United States Government or any egency thereof or its contractors or subcont ractors.

Printed in the United States of America. To obtain copies of this document, contact: WHC/BCS Document Control Services, P.O. Box 1970. Mailstop H6-08, Richland WA 99352, Phone (509) 372-2420; Fax (509) 376-4989.
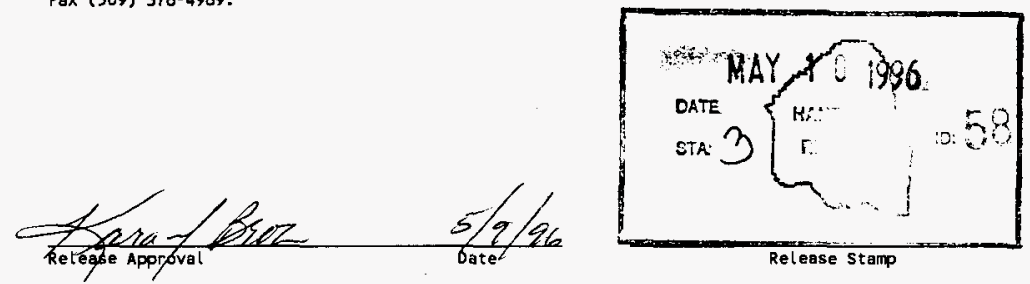

\section{Approved for Public Release}




\begin{tabular}{|c|c|c|c|}
\hline & RECORD OF REVISION & $\begin{array}{l}\text { (1) Document } \\
W H C-S D-W M-\end{array}$ & $\begin{array}{l}\text { ber } \\
P-421\end{array}$ \\
\hline $\begin{array}{l}\text { (2) ritle } \\
\text { Tank 241-B. }\end{array}$ & OB Tank Characterization Plan & & \\
\hline & CHANGE CONTROL RECORD & & \\
\hline (3) Revision & (4) Description of Change - Replace, Add, and Delete Pages & Author & zed for Release \\
\hline & 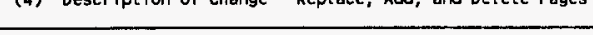 & (5) Cog. Engr. & (6) Cog. Mgr. Date \\
\hline 0 & $\begin{array}{l}\text { (7) Initially released } 01 / 02 / 96 \text { on EDT- } \\
613595 \text {. }\end{array}$ & C.S. Homi & J.G. Kristofzski \\
\hline PS 1 & Incorporate per ECN-631549. & C. S Homi & Kristofzski \\
\hline & & Pttr. & Sytant 5/9/4 \\
\hline & & & \\
\hline & & & \\
\hline & & & \\
\hline & & & \\
\hline & & & \\
\hline & & & \\
\hline & & & \\
\hline & & & \\
\hline & & & \\
\hline & & & \\
\hline & & & \\
\hline & & & \\
\hline & & & \\
\hline & & & \\
\hline & & & \\
\hline & & & \\
\hline & & & \\
\hline & & & \\
\hline & & & \\
\hline & & & \\
\hline & & & \\
\hline & & & \\
\hline & & & \\
\hline & & & \\
\hline & & & \\
\hline & & & \\
\hline & & & \\
\hline & & & \\
\hline & & & \\
\hline
\end{tabular}


WHC-SD-WM-TP-421

Revision 1

UC-2070

\title{
Tank 241-B-108 Tank Characterization Plan
}

\author{
T. A. $\mathrm{Hu}$
}

Westinghouse Hanford Company

Date Published

May 1996

Prepared for the U.S. Department of Energy

Office of Environmental Restoration and

Waste Management

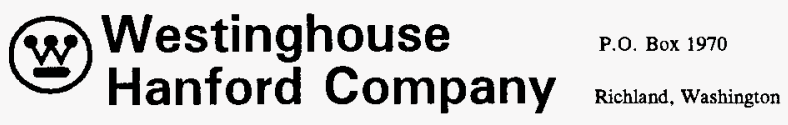

Management and Operations Contractor for the

U.S. Department of Energy under Contract DE-AC06-87RL10930 
WHC-SD-WM-TP-421, REV 1

TABLE OF CONTENTS

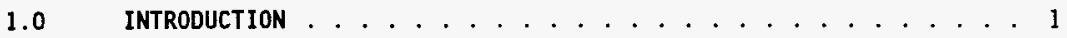

2.0 PROGRAM ELEMENTS REQUIRING INFORMATION FOR TANK 241-B-108 . . . 1

2.1 GENERAL SAFETY ISSUES . . . . . . . . . . . . 2

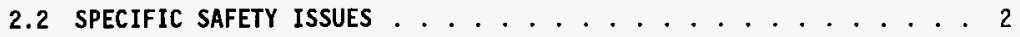

2.2 .1 Ferrocyanide ............... 2

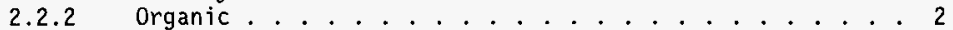

2.2 .3 High Heat ............... 2

2.2 .4 Flammable Gas ................. 2

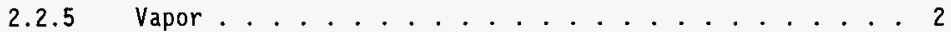

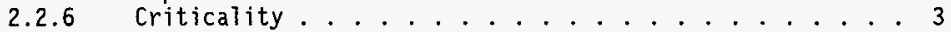

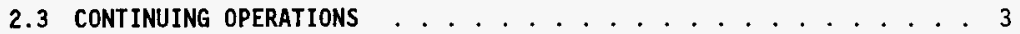

2.3.1 Compatibility/Stabilization .......... 3

2.3.2 Evaporator ................ 3

2.4 DOUBLE-SHELL TANK WASTE ANALYSIS PLAN .......... 3

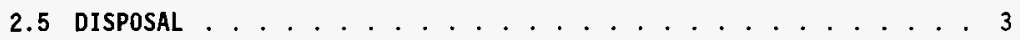

2.5.1 Retrieval ............... 3

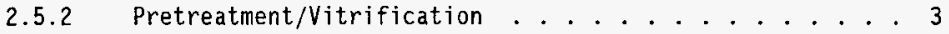

2.6 HISTORICAL MODEL EVALUATION $\ldots \ldots \ldots \ldots$

3.0 HOW INFORMATION WILL BE OBTAINED ............. 4

4.0 PRIORITY OF INFORMATION REQUIREMENTS . . . . . . . . . . 4

5.0 WHEN INFORMATION WILL BE AVAILABLE ............ 4

6.0 REFERENCES ..................... 5

\section{LIST OF TABLES}

4-1 Integrated DQO Requirements and Priorities.......... 4 
WHC-SD-WM-TP-421, REV 1

\subsection{INTRODUCTION}

This Tank Characterization Plan (TCP) identifies the information needed to address relevant issues concerning short-term and long-term safe storage and long-term management of single-shell tank 241-B-108 (B-108). It should be understood that the various needs and issues surrounding tank B-108 are evolving as new information about the tank is uncovered. As a result of this progression, this TCP addresses only the issues that, to this date, have been identified. It is expected that deviations from this plan may occur as additional issues or needs arise which impact the management of tank B-108. As necessary, this TCP will be revised to reflect those changes or deviations. This plan reflects the best information available as of May 1996.

Tank B-108 was constructed between 1943 and 1944 and was put into service in 1945. Tank B-108 was filled with first-cycle waste from the fourth quarter of 1945 to January 1946. The tank received and transferred waste via the cascade lines between 1945 and 1946 and in 1963. From the fourth quarter of 1945 to the second quarter of 1951 , the tank contained first-cycle waste. From the second quarter of 1952 until the first quarter of 1969, the tank contained evaporator bottoms waste and coating waste. The tank contained ion exchange waste from the fourth quarter of 1969 until the second quarter of 1972. The tank was suspected to be leaking the fourth quarter of 1973. From the second quarter of 1974 to the second quarter of 1976, the tank contained evaporator bottoms waste. Beginning in the fourth quarter of 1976 until the third quarter of 1977, the tank waste was diluted evaporator feed. In 1978, the tank was inactive. Presently, the tank contents are classified as non-complexed waste. Tank B-108 is categorized as sound and is interim stabilized with intrusion prevention completed (Brevick et al. 1994).

This tank currently contains a total waste volume of approximately $356 \mathrm{~kL}$ (94 $\mathrm{kgal}$ ), which is equivalent to $75 \mathrm{~cm}(30 \mathrm{in})$ of waste as measured from the baseline of the tank.

This tank is not on any Watch List.

Near-term sampling and analysis activities are focused on either verifying or changing the watch list tank status, and identifying any new safety issues. Should any safety issues be identified, additional analysis will occur consistent with the identified issue.

In addition to the resolution of the safety issues, it is intended that all tank waste will be subject to pretreatment and retrieval to prepare for final storage or disposal. Presently, these long-range plans have yet to be fully identified and are, therefore, not included in this document.

\subsection{PROGRAM ELEMENTS REQUIRING INFORMATION FOR TANK 241-B-108}

This section identifies the various program elements, and identifies which of these programs require characterization data from tank B-108. 
WHC-SD-WM-TP-421, REV 1

\subsection{GENERAL SAFETY ISSUES}

The Tank Safety Screening Data Quality Objective (Dukelow et al. 1995) describes the sampling and analytical requirements that are used to screen waste tanks for unidentified safety issues. Analytical requirements for the safety screening of a tank are energetics, total alpha activity, moisture content, density and flammable gas concentration.

\subsection{SPECIFIC SAFETY ISSUES}

\subsubsection{Ferrocyanide}

This tank is not on the Ferrocyanide Watch List; therefore, no information needs are currently identified for this program element.

\subsubsection{Organic}

This tank is not on the Organic Watch List; therefore, no information needs are currently identified for this program element.

\subsubsection{High Heat}

This tank is not on the High Heat Watch List; therefore, no information needs are currentiy identified for this program element.

\subsubsection{Flammable Gas}

This tank is not on the Flammable Gas Watch List; therefore, no information needs are currently identified for this program element.

\subsubsection{Vapor}

A11 177 underground tanks must be vapor-sampled for organic solvent screening as per Recommendation 93-5 Implementation Plan (DOE-RL 1996). Some tanks may require additional vapor sampling due to other program needs. These tanks may be classified into four categories: (1) those tanks which are to be rotary mode core sampled (as a consequence of the rotary sampling system exhauster permit requirements); (2) tanks on the Organic or Ferrocyanide Watch Lists; (3) tanks in C farm; and (4) tank 241-BX-104, due to vapor exposure. Information needs must satisfy Data Quality Objectives for Tank Hazardous Vapor Safety Screening (Osborne and Buckley 1995), and for rotary mode only, Rotary Core Vapor Sampling Data Quality Objective (Price 1994), and Data Quality Objective for Regulatory Requirements for Hazardous and Radioactive Air Emissions Sampling and Analysis (MuTkey and Markillie 1995) as amended by Status of the Current Understanding of the Toxic Air Pollutants (TAPS) and Hanford Tank Farm Vapor Space Characterization; Recommended Path Forward and Justification for Continued RMCS Exhauster Operations (Laws 1996). 


\section{WHC-SD-WM-TP-421, REV 1}

\subsubsection{Criticality}

No information separate from that for the general safety issue of tank B-108 are currently identified for this program element. However, if the general safety screening of tank B-108 identifies a potential criticality concern, analyses for fissile materials and neutron sorbers and poisons will be performed as identified in the safety screening data quality objective (DQO).

\subsection{CONTINUING OPERATIONS}

\subsubsection{Compatibility/Stabilization}

This section does not apply to tank B-108.

\subsubsection{Evaporator}

This section does not apply to tank B-108.

\subsection{DOUBLE-SHELL TANK WASTE ANALYSIS PLAN}

This section does not apply because tank B-108 is a single-shell tank.

\subsection{DISPOSAL}

\subsubsection{Retrievai}

Current retrieval needs (B1oom and Nguyen 1995) do not call for test samples to be taken from tank B-108.

\subsubsection{Pretreatment/Vitrification}

Tank B-108 has not been identified as a bounding tank for pretreatment/ disposal process development strategy (Kupfer et a1. 1995). A11 tanks were prioritized using the pretreatment strategy in the Tank Waste Characterization Basis (Brown et a). 1995) document and a portion of archive sample material could be used for pretreatment testing if available. The strategy does not require any specific analyses to be done on the samples.

\subsection{HISTORICAL MODEL EVALUATION}

Bounding tanks and data requirements for historical model evaluations are found in Historical Model Evaluation Data Requirements (Simpson and McCain 1995). Tank B-108 has been identified as a primary bounding tank for the B salt cake waste types. All single-shell tanks were prioritized in the Tank Waste Characterization Basis (Brown et a1. 1995) document using the historical DQO. 
WHC-SD-WM-TP-421, REV 1

\subsection{HOW INFORMATION WILL BE OBTAINED}

The number of samples required to characterize a tank is a function of waste heterogeneity and the desired confidence to make a correct decision. directed by the safety screening $0 Q 0$, if inadequate information exists to determine an appropriate number of samples, two vertical profiles will be obtained. These vertical profiles may be obtained using core, auger (for shallow tanks), or grab samples. If analys is of these profiles reveals that additional profiles are necessary to meet data needs, more sample profiles will be requested.

\subsection{PRIORITY OF INFORMATION REQUIREMENTS}

Vapor sampling is scheduled to begin in July 1997. Push mode core sampling is scheduled to begin in August 1997 (Stanton 1996). Refer to Table 4-1 for the current DQO requirements and planned sampling and analytical requirements.

Table 4-1: Integrated DQO Requirements and Priorities

\begin{tabular}{||l|l|l|l||}
\hline $\begin{array}{l}\text { Sampling } \\
\text { Event }\end{array}$ & \multicolumn{1}{|c|}{ Applicable Issues } & Sampling Requirements & \multicolumn{1}{|c||}{$\begin{array}{c}\text { Analytical } \\
\text { Requirements }\end{array}$} \\
\hline $\begin{array}{l}\text { Vapor } \\
\text { Sampling }\end{array}$ & $\begin{array}{l}\text {-Organic Solvent Layer } \\
\text { 93-5 Vapor Issue } \\
\text {-Hazardous Vapor DQ0 }\end{array}$ & $\begin{array}{l}\text { Steel canisters, } \\
\text { Triple Sorbent Traps, } \\
\text { Sorbent Trap Systems }\end{array}$ & $\begin{array}{l}\text { Flammable Gas } \\
\text { Organic Vapors } \\
\text { Permanent Gases }\end{array}$ \\
\hline $\begin{array}{l}\text { Push Mode } \\
\text { Core } \\
\text { Sampling }\end{array}$ & $\begin{array}{l}\text {-Safety Screening DQ0 } \\
\text {-Historical Model DQO }\end{array}$ & $\begin{array}{l}\text { Core samples from 2 } \\
\text { risers separated } \\
\text { radially to the maximum } \\
\text { extent possible } \\
\text { Combustible gas } \\
\text { measurement }\end{array}$ & $\begin{array}{l}\text { Flammability, } \\
\text { Energet ics, Moisture, } \\
\text { Total alpha activity, } \\
\text { Density, Anions, } \\
\text { Metals, Total Organic } \\
\text { Carbon, Radionuclides }\end{array}$ \\
\hline
\end{tabular}

* Consult each applicable DQO in force at the time for sampling and analytical requirements.

\subsection{WHEN INFORMATION WILL BE AVAILABLE}

According to Stanton (1996), data are expected to be available from the vapor sampling event for tank B-108 in August 1997. The push mode core data are expected in December 1997. These times may be altered if the sampling schedule changes. 


\section{WHC-SD-WM-TP-421, REV 1}

\subsection{REFERENCES}

Bloom, G. R. and Q. H. Nguyen, 1995, Characterization Data Needs for Development, Design and Operation of Retrieval Equipment Developed Through the Data Quality Objective Process, WHC-SD-WM-DQ0-008, Rev. 0, Westinghouse Hanford Company, Richland, Washington.

Brevick, C. H., L. A. Gaddis, and E. D. Johnson, 1994, Supporting Document for the Northeast Quadrant Historical Tank Content Estimate for B-Tank Farm, WHC-SD-WM-ER-310, Rev. 0, Westinghouse Hanford Company, Richland, Washington.

Brown, T. M., S. J. Eberlein, and T. J. Kunthara, 1995, Tank Waste Characterization Basis, WHC-SD-WM-TA-164, Rev. 1, Westinghouse Hanford Company, Richland, Washington.

DOE-RL, 1996, Recommendation 93-5 Implementation Plan, DOE/RL-94-0001, Rev. 1, U.S. Department of Energy, Richland, Washington.

Dukelow, G. T., J. W. Hunt, H. Babad, and J. E. Meacham, 1995, Tank Safety Screening Data Quality objective, WHC-SD-WM-SP-004, Rev. 2, Westinghouse Hanford Company, Richland, Washington.

Hanion, B.M., 1996, Waste Tank Summary for Month Ending January 31, 1996, WHC-EP-0182-94, Westinghouse Hanford Company, Richland, Washington.

Kupfer, M. J., W. W. Schultz, and J. T. Slankas, 1995, Strategy for Sampling Hanford Site Tank Wastes for Development of Disposal Technology, WHC-SD-WM-TA-154, Rev. 1, Westinghouse Hanford Company, Richland, Washington.

Laws, G. L., 1996, Status of the Current Understanding of the Toxic Air Pollutants (TAPS) and Hanford Tank Farm Vapor Space Characterization; Recommended Path Forward and Justification for Continued RMCS Exhauster Operations, (telephone conference memorandum, 01830-96-022, to Distribution, March 8) Westinghouse Hanford Company, Richland, Washington.

Mulkey, C.H., and K. D. Markillie, 1995, Data Quality Objective for Regulatory Requirements for Hazardous and Radioactive Air Emissions Sampling and Analysis, WHC-SD-WM-DQ0-021, Rev. 0, Westinghouse Hanford Company, Richland, Washington.

Osborne, J. W. and L. L. Buckley, 1995, Data Quality Objectives for Tank Hazardous Vapor Safety Screening, WHC-SD-WM-DQ0-002, Rev. 2, Westinghouse Hanford Company, Richland, Washington.

Price, D. N., 1994, Rotary Core Vapor Sampling Data Quality Objective, WHC-SD-WM-SP-003, Rev. 0, Westinghouse Hanford Company, Richland, Washington. 


\section{WHC-SD-WM-TP-421, REV 1}

Simpson, B. C., and D. J. McCain, 1995, Historical Model Evaluation Data Requirements, WHC-SD-WM-DQO-018, Rev. OA, Westinghouse Hanford Company, Richland, Washington.

Stanton, G. A., 1996, Baseline Sampling Schedule, Change 96-02, (internal memo 75610-96-06, to Distribution, April 17), Westinghouse Hanford Company, Richland, Washington. 


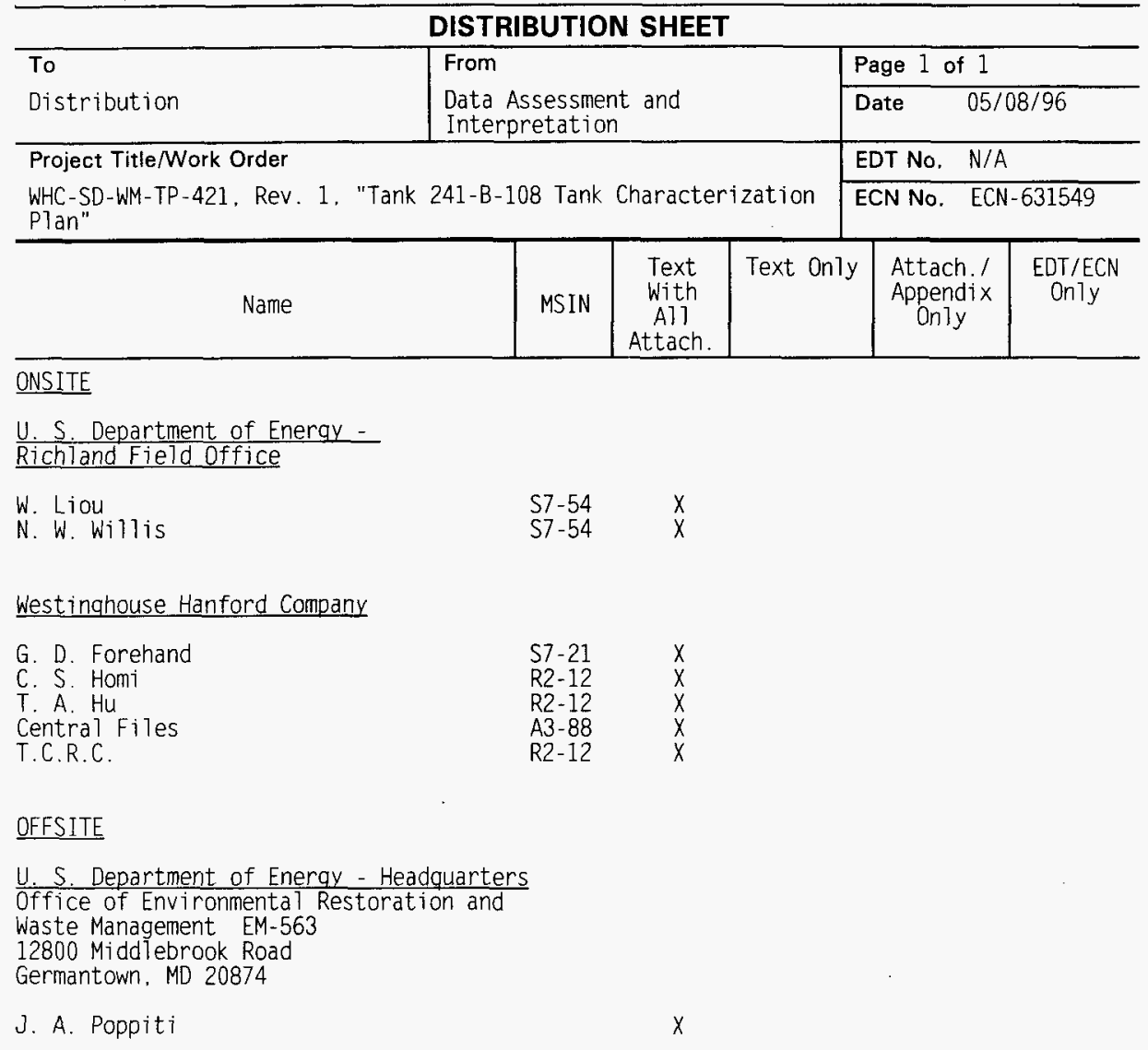

